\title{
Kualitas Pencahayaan Alami pada Gang di Kawasan Kampung Kota Terhadap Aktivitas
}

\author{
Eggi Septianto, Adi Kusmayadi, Ditta Fadhilah, Intan Fadila Noor Fajriani, Hanifah \\ Nur Nadiyah
}

\author{
Jurusan Arsitektur, Fakultas Teknik Sipil dan Perencanaan, Itenas, Bandung \\ Email : eggi@itenas.ac.id
}

\begin{abstract}
ABSTRAK
Perkembangan permukiman di daerah perkotaan berbanding lurus dengan pertumbuhan penduduk. Ciri yang menonjol dari permukiman di kampung kota adalah gang sempit, kerapatan bangunan yang tinggi dan ketinggian bangunan yang beragam. Gang di permukiman kampung-kota tidak hanya berfungsi sebagai sarana sirkulasi tetapi juga menjadi sarana berbagai aktivitas masyarakat lainnya dalam menjalankan kehidupan sehari-hari. Kualitas pencahayaan di kampung kota yang padat memiliki pengaruh sangat besar terhadap kenyamanan, keamanan, dan keselamatan. Pada penelitian ini, analisa dilakukan pada kondisi fisik bangunan terhadap kualitas pencahayaan yang terkait aktivitas masyarakat bertujuan untuk mengetahui bagaimana kualitas pencahayaan terhadap aktivitas pada gang di kawasan kampung kota. Kawasan yang menjadi objek pengamatan adalah perkampungan di daerah Sukasenang, Kelurahan Cikutra, Kecamatan Cibeunying Kidul, Kota Bandung karena dianggap dapat mewakili karakteristik kampung - kota yang ada di Bandung. Hasil penelitian ini dapat dijadikan sebagai alternatif penentuan rasio dan arah jalur sirkulasi yang baik dalam memperoleh kualitas pencahayaan optimal dan layak untuk melakukan aktivitas pada gang kampung kota.
\end{abstract}

Kata Kunci : gang, kondisi fisik, aktivitas, pencahayaan alami.

\begin{abstract}
The development of settlements in urban areas is directly proportional to the population of growth. A prominent feature of the village settlements in the city is a narrow alley, building high density and height of buildings that vary. Alleys in the hometown not only serves as a means of circulation but also a means of various other community activities in performing daily life Quality lighting in the crowded hometown has a very big influence on comfort, security, and safety. In this study, the analysis conducted on the physical condition of the building on the quality of lighting-related community activities aimed to determine how the quality of light on the activities of the alleys in the hometown area of the city. Regions that become the object of observation is a village in the area Sukasenang, Village Cikutra, District Cibeunying Kidul, Bandung City. because it is considered to represent the characteristics of the hometown in Bandung. The results of this study can be used as an alternative to the determination of the ratio and good circulation path toward obtaining optimal lighting quality and worth to conduct activities in the alleys of howmetown.
\end{abstract}

Keywords : alleys, physical condition, activity, natural lighting. 


\section{PENDAHULUAN}

Perkembangan permukiman di daerah perkotaan berbanding lurus dengan pertumbuhan penduduk. Lingkungan permukiman yang memenuhi persyaratan keamanan, kesehatan, kenyamanan serta keandalan bangunan merupakan lingkungan yang baik dan layak untuk dihuni. Ciri yang menonjol dari permukiman di kampung kota adalah gang sempit, kerapatan bangunan yang tinggi dan ketinggian bangunan yang beragam yang kemudian berdampak pada fasilitas lingkungan, salah satunya yaitu fasilitas pejalan kaki berupa lorong atau gang.

Gang di permukiman kampung-kota tidak hanya menjadi ruang jalan yang berfungsi sebagai sarana sirkulasi untuk menghubungkan satu tempat ke tempat lain tetapi juga menjadi sarana berbagai aktivitas masyarakat lainnya dalam menjalankan kehidupan sehari-hari (Ramelan,2007). Pencahayaan alami menjadi salah satu faktor yang dipengaruhi oleh kerapatan dan ketinggian bangunan serta memiliki pengaruh sangat besar terhadap kenyamanan, keamanan, dan keselamatan pengguna.

Objek kajian dalam tulisan ini adalah kualitas pencahayaan alami pada Kampung Sukasenang, RT0105, RW 15, Kelurahan Cikutra, Kecamatan Cibeunying Kidul, Kota Bandung, dapat dilihat pada Gambar 1. Penelitian ini dilakukan dengan variabel kontrol yaitu arah mata angin dan variabel kajian yaitu kondisi fisik jalur sirkulasi berupa tinggi bangunan dan lebar jalan, kualitas pencahayaan serta aktivitas masyarakat pada kawasan penelitian. Penelitian ini bertujuan untuk menganalisa pengaruh kondisi fisik jalur sirkulasi terhadap kualitas pencahayaan alami yang terjadi sepanjang gang pemukiman padat di kawasan Sukasenang yang dapat mempengaruhi aktivitas masyarakat yang terjadi pada jalur tersebut.

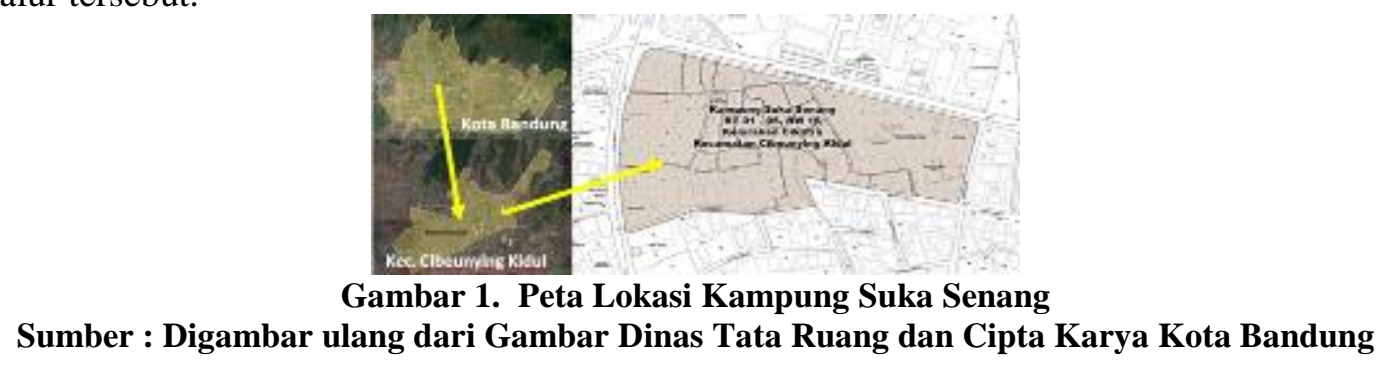

Pencahayaan didefinisikan sebagai jumlah cahaya yang jatuh pada sebuah bidang permukaan. Pencahayaan alami adalah pencahayaan yang memiliki sumber cahaya yang berasal dari alam, seperti matahari, bintang, dll. Matahari adalah sumber pencahayaan alami yang paling utama, namun sumber pencahayaan ini tergantung kepada waktu (siang hari atau malam hari), musim, dan cuaca (cerah, mendung, berawan, dll).

\section{METODOLOGI}

Metoda yang dilakukan yaitu metoda kualitatif dan kuantitatif. Dengan metode ini, penulis memutuskan untuk mengamati kawasan Sukasenang, Cibeunying Kidul, Bandung sebagai objek kajian. Metoda kuantitatif dilakukan dengan mengukur kondisi fisik yakni tinggi bangunan dan lebar jalan kemudian mengukur pencahayaan yang terjadi pada pagi, siang, dan sore hari serta menganalisa hasil pengukuran terhadap aktivitas masyarakat pada kawasan pengamatan terkait kualitas pencahayaan. Proses penelitian yang dilakukan meliputi pengumpulan data dengan melakukan survey lapangan untuk mengetahui kondisi fisik dengan mengukur tinggi bangunan dan lebar jalan pada area penelitian kemudian membaginya kedalam beberapa kelompok tipologi untuk mempermudah proses analisa. Hasil pengolahan data disajikan dalam bentuk kuantitatif lalu menganalisa dengan metode deskriptif kualitatif. Pengumpulan data terhadap kondisi fisik, pencahayaan dan aktivitas masyarakat bertujuan untuk memperoleh perbandingan kualitas pencahayaan yang ditinjau dari parameter perbandingan arah mata angin sehingga efektifitas kualitas pencahayaan dapat diketahui, baik dari segi rasio kondisi fisik maupun orientasi gang. Pengukuran dilakukan pada kondisi cuaca cerah pada 3 term waktu (pagi pukul 08.00-10.00, siang pukul 11.00-14.00 dan sore pukul 15.00-17.00) menggunakan alat ukur cahaya pada Gambar 2. Pada proses analisa menggunakan metoda kualitatif yaitu pada analisis hasil pengukuran. Praktikan membandingkan hasil pengukuran dengan standar pencahayaan berdasarkan standar SNI dan standar teori pencahayaan. Pada analisa kualitas 
pencahayaan, penulis menghitung besar pencahayaan yang terjadi dan membandingkan data ekisting dengan standar, sehingga didapatkan wilayah-wilayah dengan pencahayaan optimal, memenuhi dan tidak memenuhi.

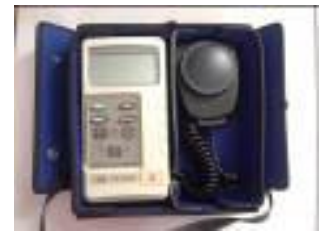

Gambar 2. Alat Ukur Cahaya Luxmeter Sumber : hasil survey 2016

\section{HASIL DAN PEMBAHASAN}

\subsection{Teori Variabel Kajian}

Gang yaitu jalan kecil (di kampung-kampung dalam kota) [1]. Kondisi fisik yang akan dikaji yaitu ketinggian bangunan dan lebar jalan. Skala sebuah tempat akan mempengaruhi kesan terhadap konteks tempat tersebut. Walaupun kesan sebuah tempat tergantung pada banyak faktor, bisa dikatakan secara umum bahwa skala, yaitu hubungan antara lebar/panjang dan tinggi ruang dari sebuah tempat, memberikan sebuah kesan yang bersifat agak umum pada orang yang bergerak di dalamnya [2]. Pencahayaan didefinisikan sebagai jumlah cahaya yang jatuh pada sebuah bidang permukaan. Pencahayaan alami adalah pencahayaan yang memiliki sumber cahaya yang berasal dari alam, seperti matahari, bintang, dll. Matahari adalah sumber pencahayaan alami yang paling utama, namun sumber pencahayaan ini tergantung kepada waktu (siang hari atau malam hari), musim, dan cuaca (cerah, mendung, berawan, dll) [3]. Aktivitas pendukung adalah semua fungsi bangunan dan kegiatan-kegiatan yang mendukung ruang kontrol suatu kawasan kota [4].

\subsection{Standarisasi Pencahayaan}

Kuat pencahayaan pada terowongan harus cukup dan memberi kenyamanan baik untuk penglihatan siang maupun malam hari dapat dilihat pada Tabel 1.

Tabel 1. Batasan kuat pencahayaan pada terowongan

\begin{tabular}{|c|c|c|c|}
\hline \multirow{2}{*}{ Jenis/Klasifikasi Jalan } & \multicolumn{3}{|c|}{ Daerah Penempatan (Lux) } \\
\hline & Komersil & Menengah & Permukiman \\
\hline Jalan arteri dengan kontrol/jalan bebas hambatan & 22 & 15 & 11 \\
\hline Jalan Arteri & 15 & 13 & 11 \\
\hline Jalan Kolektor & 13 & 10 & 6 \\
\hline Jalan Lokal & 10 & 6 & 4 \\
\hline Jalan Kecil/Lorong/Gang & 6 & 4 & 4 \\
\hline
\end{tabular}

Sumber : [3]

Kualitas penerangan memiliki beberapa tingkatan yang disesuaikan dengan jenis aktivitas dapat dilihat pada Tabel 2.

Tabel 2. Tabel Gabungan Klasifikasi Pola Aktivitas Berdasarkan Standarisasi Dan Teori

\begin{tabular}{|c|l|c|c|c|}
\hline & \multicolumn{1}{|c|}{ Definisi } & SNI & $\begin{array}{c}\text { Teori Pencahayaan } \\
\text { Untuk Mata Manusia }\end{array}$ & Ket. \\
\hline \multirow{2}{*}{$\begin{array}{c}\text { Kegiatan } \\
\text { Kasar }\end{array}$} & $\begin{array}{l}\text { Kegiatan yang tidak memerlukan tingkat } \\
\text { pencahayaan yang yang kuat tetapi pengguna dapat } \\
\text { melakukan aktivitasnya dengan nyaman. }\end{array}$ & $\begin{array}{c}\text { Standarisasi Untuk Lorong/ Gang } \\
\text { area permukiman } \\
: 4 \text { lux }\end{array}$ & \begin{tabular}{c} 
Untuk area sirkulasi \\
\cline { 3 - 5 }
\end{tabular} & $\begin{array}{c}\text { Untuk area yang tidak } \\
\text { digunakan terus } \\
\text { menerus }\end{array}$ \\
\hline $\begin{array}{c}\text { Kegiatan } \\
\text { Halus }\end{array}$ & $\begin{array}{l}\text { Kegiatan ini membutuhkan tingkat pencahayaan yang } \\
\text { sedikit maksimal, karena pengguna dapat melakukan } \\
\text { kegiatan yang membutuhkan konsentrasi sedang. }\end{array}$ & $\begin{array}{c}\text { Standarisasi Untuk Lorong/ Gang } \\
\text { area permukiman } \\
: 4 \text { lux }\end{array}$ & 100 Lux & Tabel 2.3. No. 2 \\
\hline $\begin{array}{c}\text { Kegiatan } \\
\text { Detail }\end{array}$ & $\begin{array}{l}\text { Kegiatan yang mengharuskan penggunanya } \\
\text { mendapatkan pencahayaan yang Optimal, karena } \\
\text { dalam hal ini pengguna mengerjakan pekerjaan yang } \\
\text { detail dan membutuhkan konsentrasi tinggi. }\end{array}$ & $\begin{array}{c}\text { Standarisasi Untuk Lorong/ } \\
\text { Gang area permukiman } \\
: 4 \text { lux }\end{array}$ & 350 Lux & Tabel 2.4 (No.3) \\
\cline { 2 - 5 }
\end{tabular}

\subsection{Hasil survey dan analisa}

Sumber : [3] dan [5] 
Kampung Sukasenang yang berada di Kelurahan Cikutra, Kecamatan Cibeunying Kidul, Kota Bandung. Kampung tersebut berada di area seluas 9,3 Ha masuk ke daerah RW15 yang terbagi ke dalam 7 RT. Menurut data kelurahan Cikutra tahun 2016, kampung tersebut dihuni oleh 518 KK dengan jumlah penduduk 1.699 jiwa. Area pengamatan terdiri dari 5 RT yaitu pada Kampung Sukasenang RW15, RT01-05. Dan berbatasan dengan Jalan PH.H. Mustofa pada arah Utara, Jalan Pahlawan pada arah Barat, Jalan Sukasenang VI di arah Selatan, dan Jalan Sukasenang di arah Timur. Hasil survey dan analisa dapat dilihat pada Tabel 3, Tabel 4, Tabel 5 dan Tabel 6.

Tabel 3. Kondisi Eksisting lokasi kajian

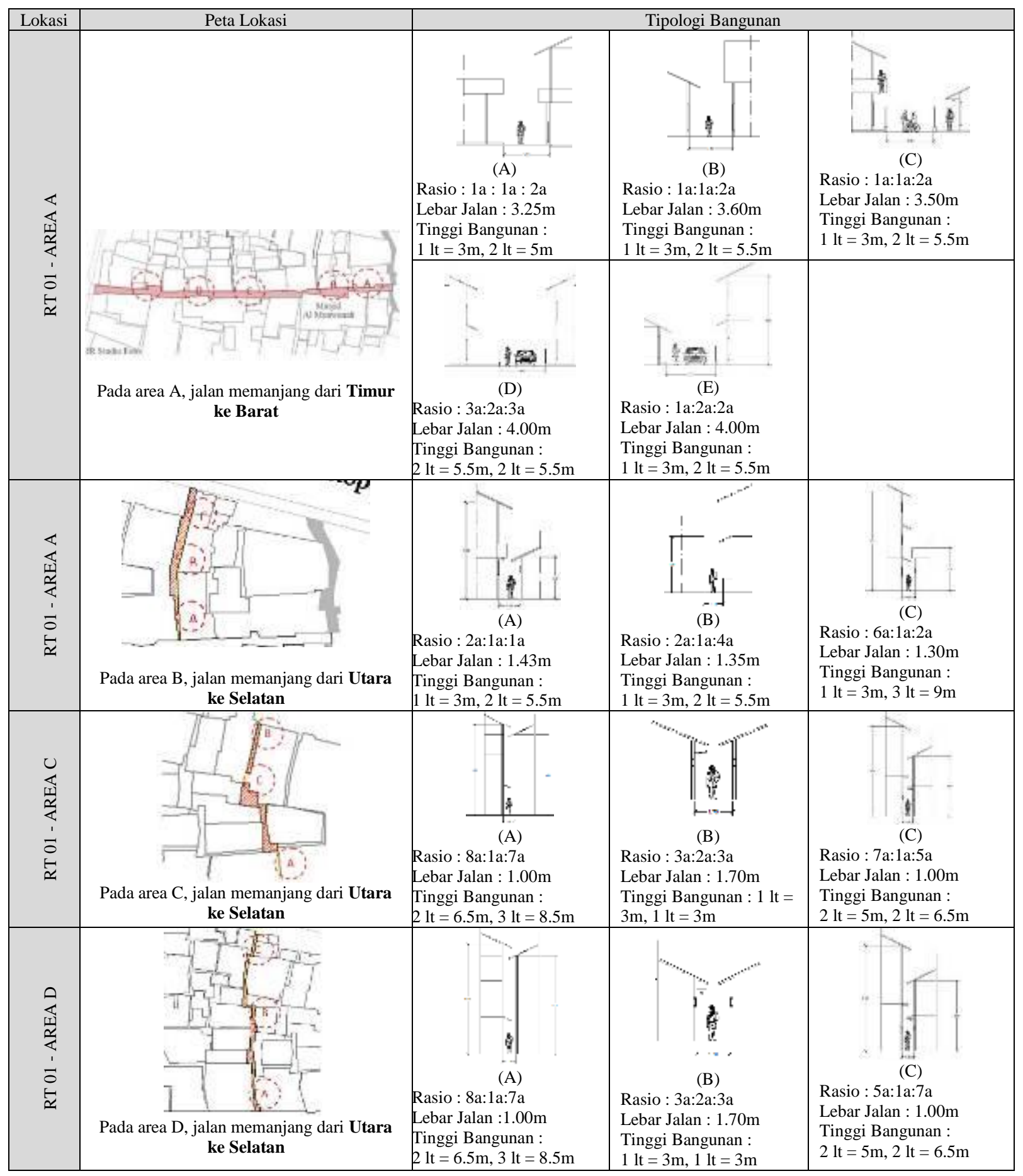




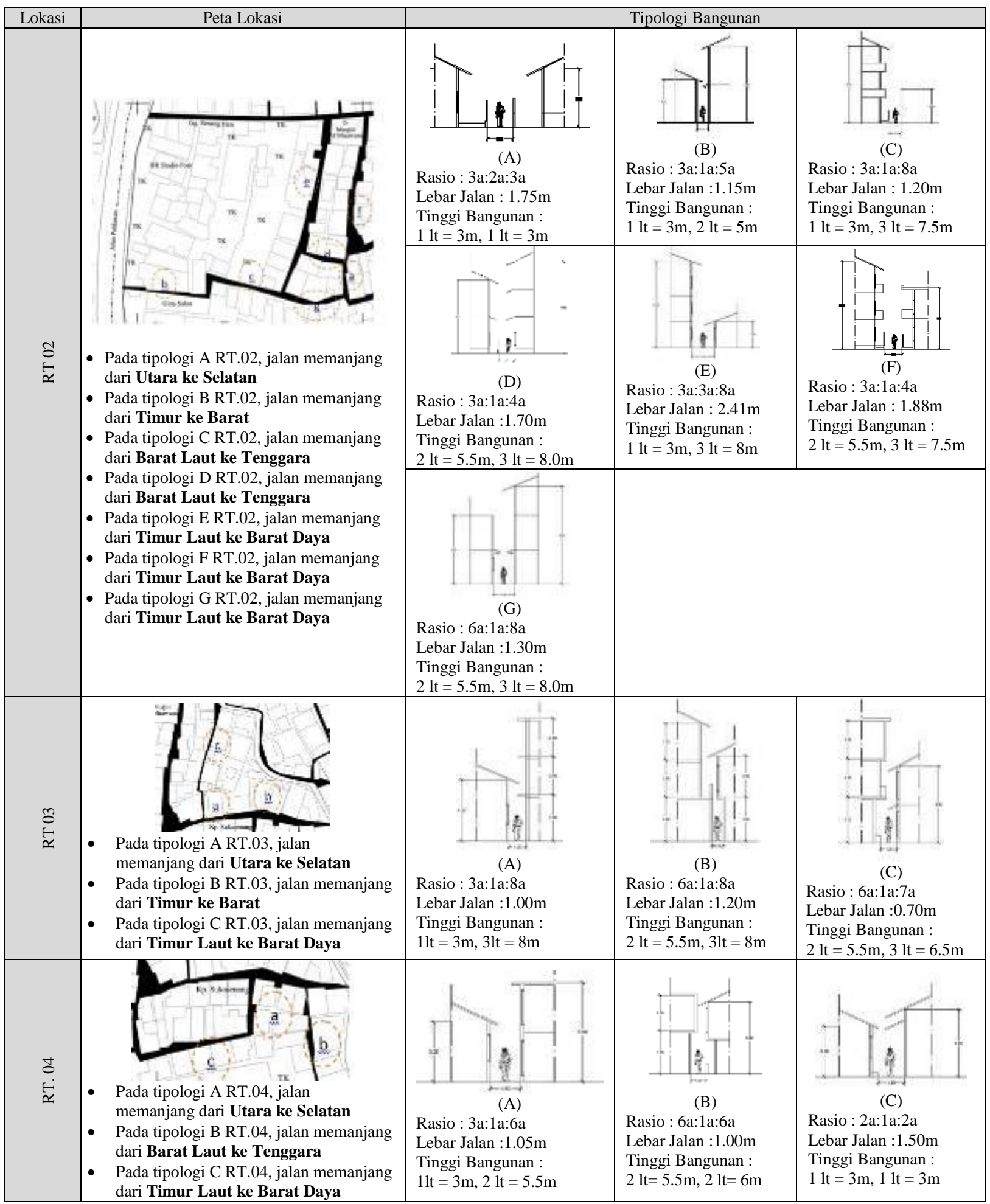




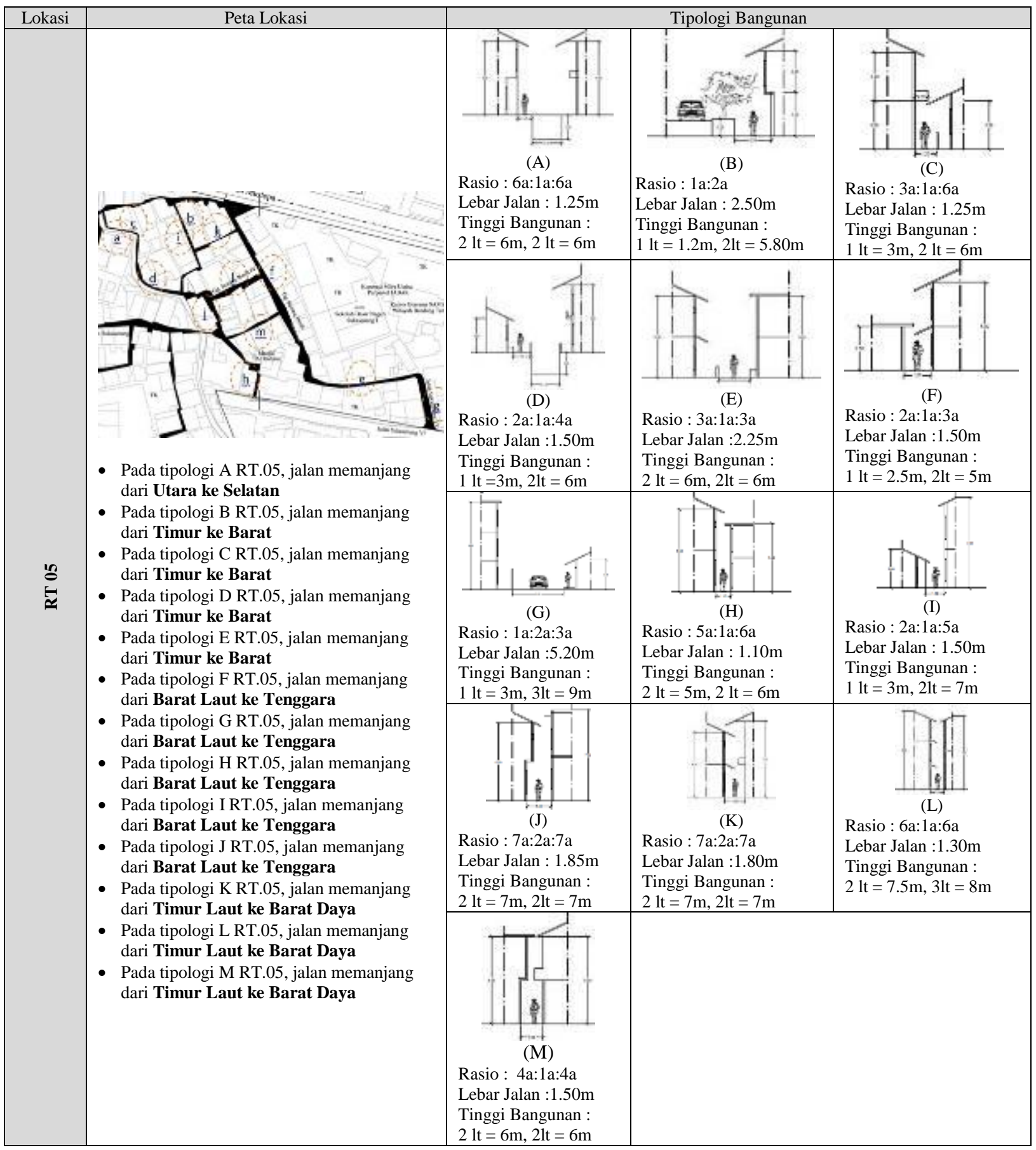

Tabel 4. Kondisi Hasil Pengukuran Pencahayaan

\begin{tabular}{|c|c|c|c|c|}
\hline Lokasi & Peta Lokasi & \multicolumn{3}{|c|}{ Hasil pengukuran pencahayaan (lux) } \\
\hline 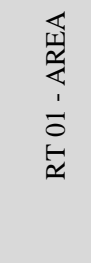 & $\begin{array}{c}\text { Pada area A, jalan memanjang dari Timur } \\
\text { ke Barat }\end{array}$ & $\begin{array}{l}\text { Pagi : }>20000 \text { lux } \\
\text { Piang: }>20000 \text { lux } \\
\text { Sore : } 760 \text { lux }\end{array}$ & \begin{tabular}{l}
\multicolumn{1}{c}{$(\mathrm{B})$} \\
Pagi : 1040 lux \\
Siang:> 20.000 lux \\
Sore : 831 lux
\end{tabular} & $\begin{array}{l}c \\
(\mathrm{C}) \\
\text { Pagi : }>20.000 \text { lux } \\
\text { Siang : > 20.000 lux } \\
\text { Sore : } 928 \text { lux }\end{array}$ \\
\hline
\end{tabular}




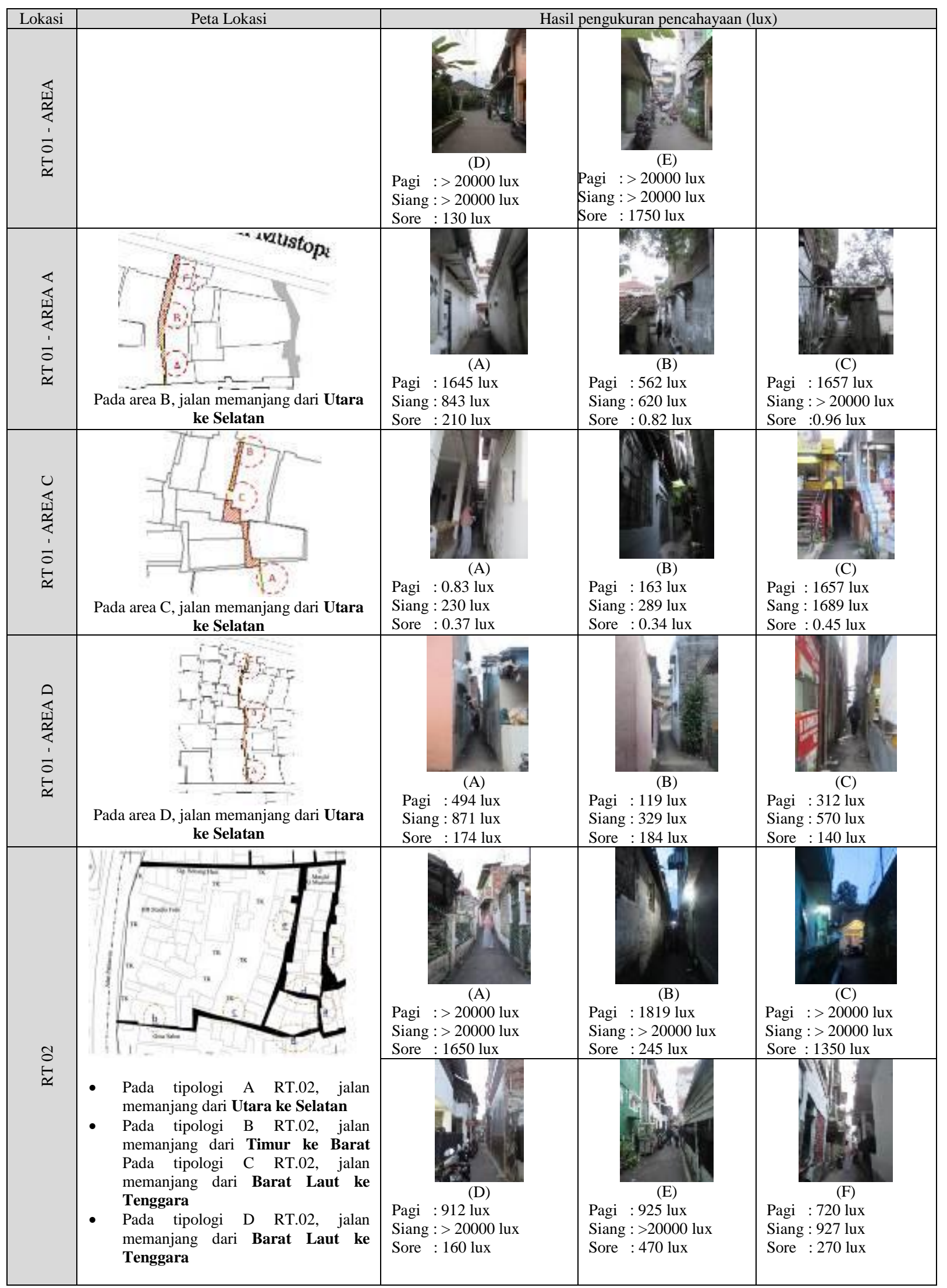




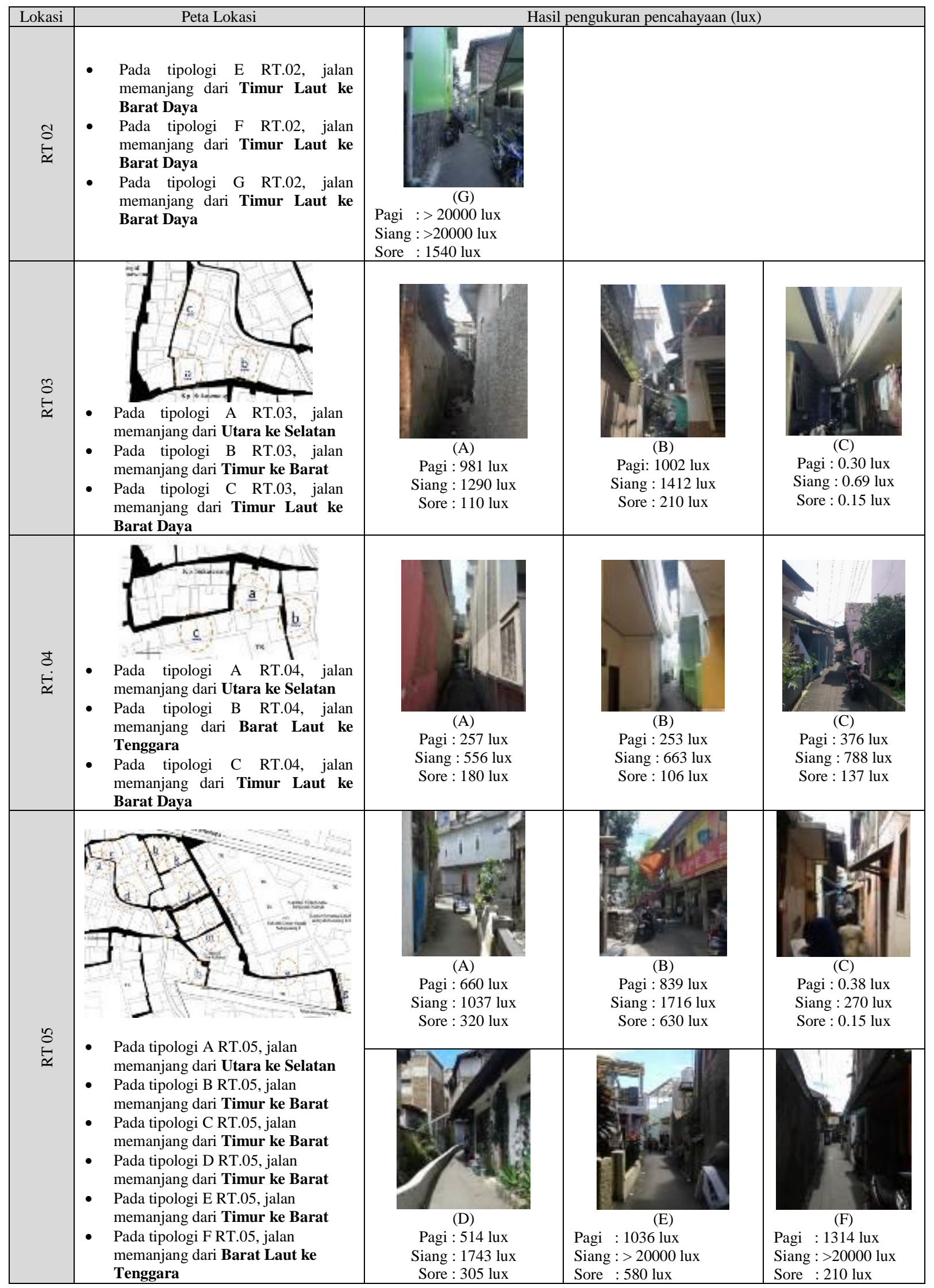




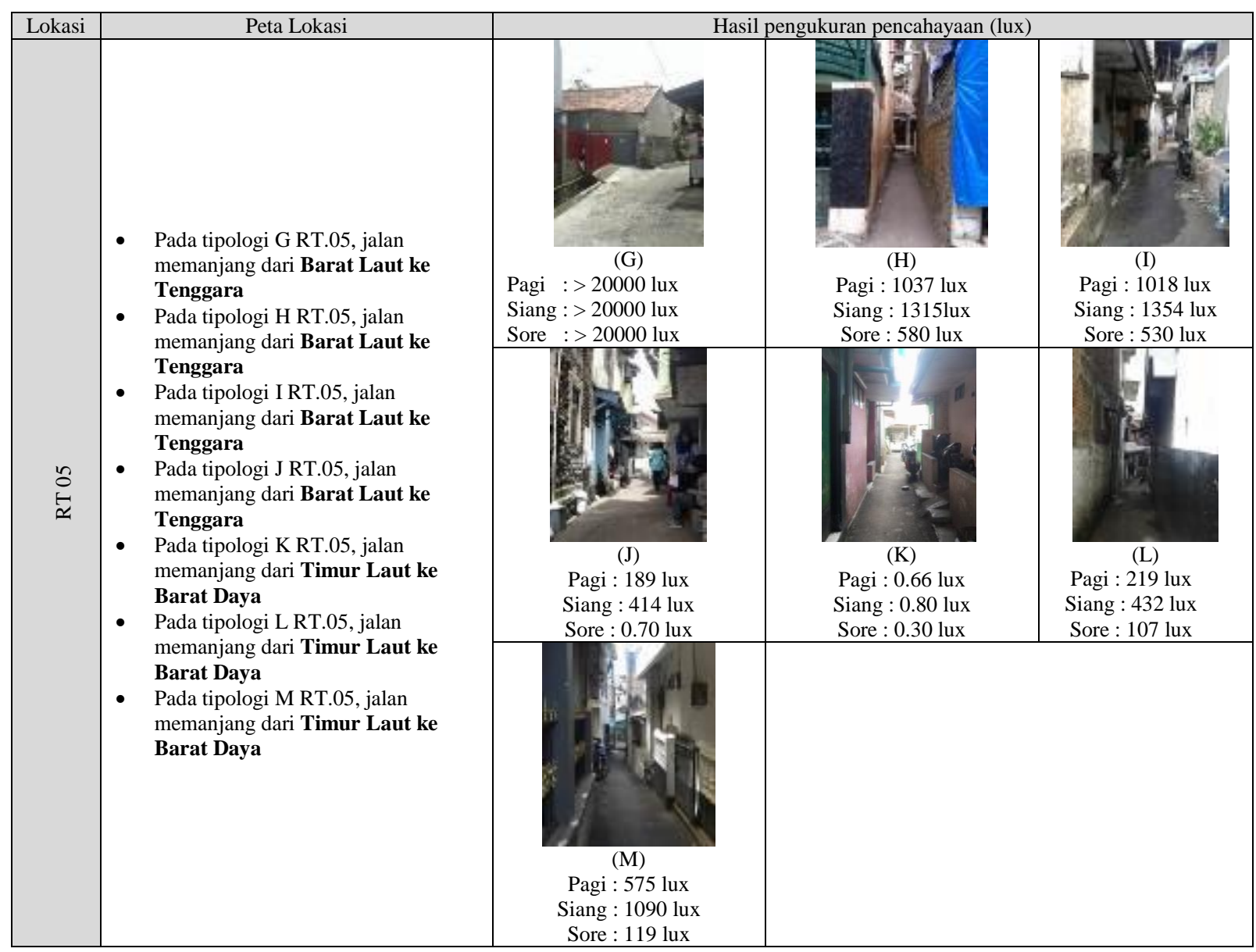

Tabel 5. Tabel Aktivitas

\begin{tabular}{|c|c|c|c|c|c|c|c|c|}
\hline Lokasi & Peta Lokasi & \multicolumn{7}{|c|}{ Aktivitas } \\
\hline \multirow{13}{*}{ 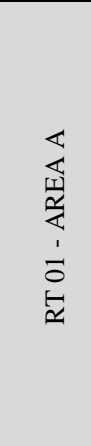 } & \multirow{13}{*}{$\begin{array}{l}\text { Pada area A, jalan memanjang dari } \\
\text { Timur ke Barat }\end{array}$} & \multicolumn{5}{|l|}{ Berjalan } & \multirow{7}{*}{\multicolumn{2}{|c|}{ Kasar }} \\
\hline & & \multicolumn{5}{|l|}{ Bermain } & & \\
\hline & & \multicolumn{5}{|l|}{ Berbincang-bincang } & & \\
\hline & & \multicolumn{5}{|l|}{ Berkendara } & & \\
\hline & & \multicolumn{5}{|l|}{ Parkir Kendaraan } & & \\
\hline & & \multicolumn{5}{|l|}{ Berlari } & & \\
\hline & & \multicolumn{5}{|l|}{ Berdiskusi } & & \\
\hline & & \multicolumn{5}{|l|}{ Makan dan Minum } & \multirow{3}{*}{\multicolumn{2}{|c|}{ Halus }} \\
\hline & & \multicolumn{5}{|c|}{ Membersihkan lingkungan } & & \\
\hline & & \multicolumn{5}{|c|}{ Berjualan/ Membeli } & & \\
\hline & & \multicolumn{5}{|l|}{ Belajar } & \multirow{2}{*}{\multicolumn{2}{|c|}{ Detail }} \\
\hline & & \multicolumn{5}{|l|}{ Mengerjakan Tugas } & & \\
\hline & & \multicolumn{7}{|c|}{ Titik Pengamatan (A), (B), (C), (D), (E) } \\
\hline \multirow{13}{*}{ 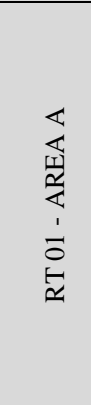 } & & Betjalan & \multirow{7}{*}{ Kasar } & Becjalan & \multirow{5}{*}{ Kasar } & & \multirow{6}{*}{ Kasar } \\
\hline & & Bermain & & Bethinsang-bizeng & & & & \\
\hline & & Betrinu:enghincang & & Beckendera (twoton) & & & & \\
\hline & & Bersatdara & & Beclari & & & & \\
\hline & & Parkir Kecdara:a & & Bendiskusi & & & & \\
\hline & & Berlan & & Nembersilisan lingsuagan & Halus & & & \\
\hline & & Berdiskusi & & \multirow{7}{*}{\multicolumn{2}{|c|}{ (B) }} & \multicolumn{2}{|c|}{ 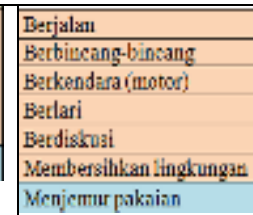 } & Halus \\
\hline & & Makan San kinum & & & & \multirow{6}{*}{\multicolumn{3}{|c|}{$(\mathrm{C})$}} \\
\hline & & Membarsihkan lingkung:en & Halus & & & & & \\
\hline & $\ldots$ & Berjualan' Membel: & & & & & & \\
\hline & \multirow{3}{*}{$\begin{array}{c}\text { Pada area B, jalan memanjang dari } \\
\text { Utara ke Selatan }\end{array}$} & Belajar & Drtvil & & & & & \\
\hline & & Mangyrjakan Tugax & Dela1I & & & & & \\
\hline & & (A) & & & & & & \\
\hline
\end{tabular}




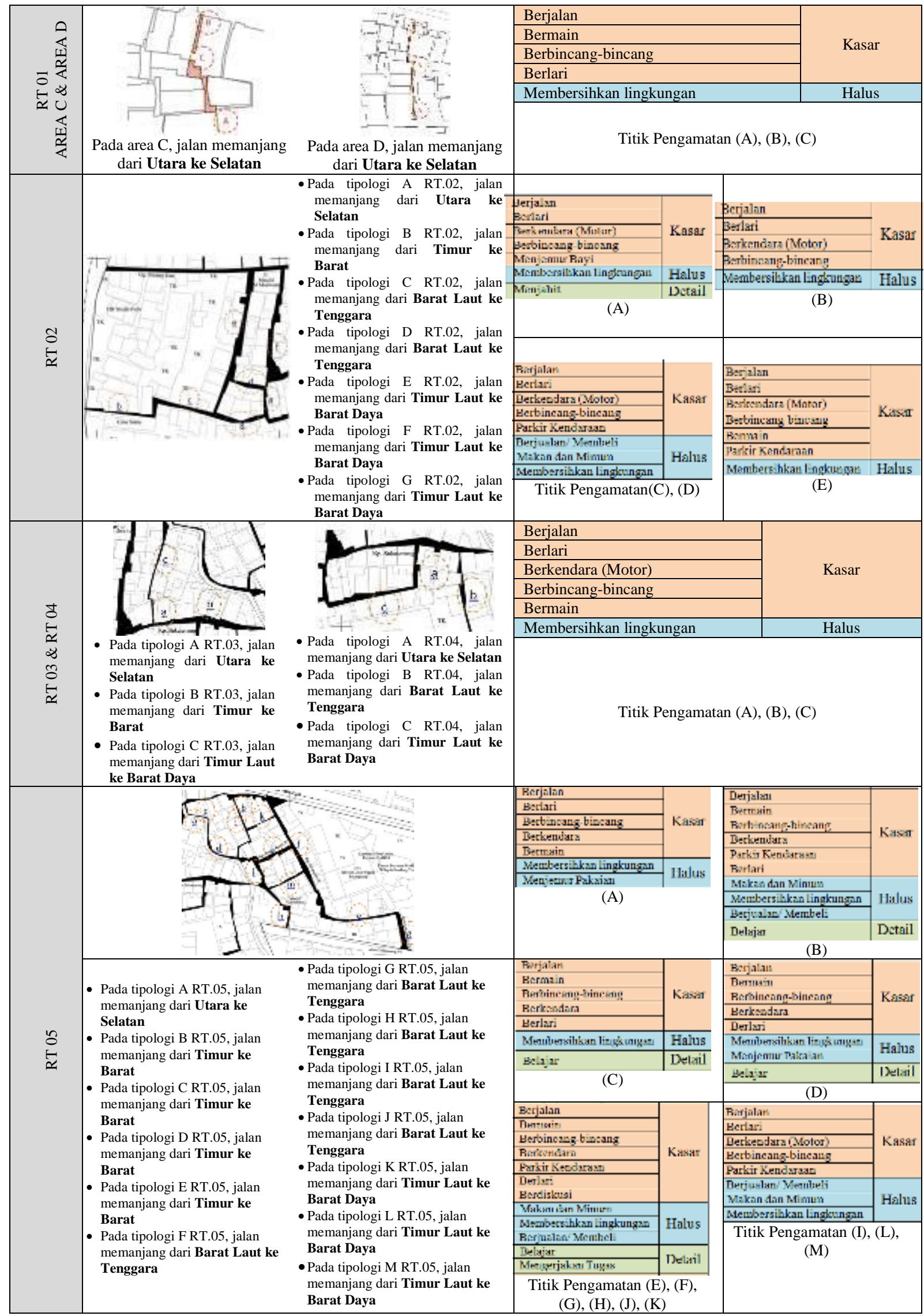

Tabel 6. Hasil Analisa 


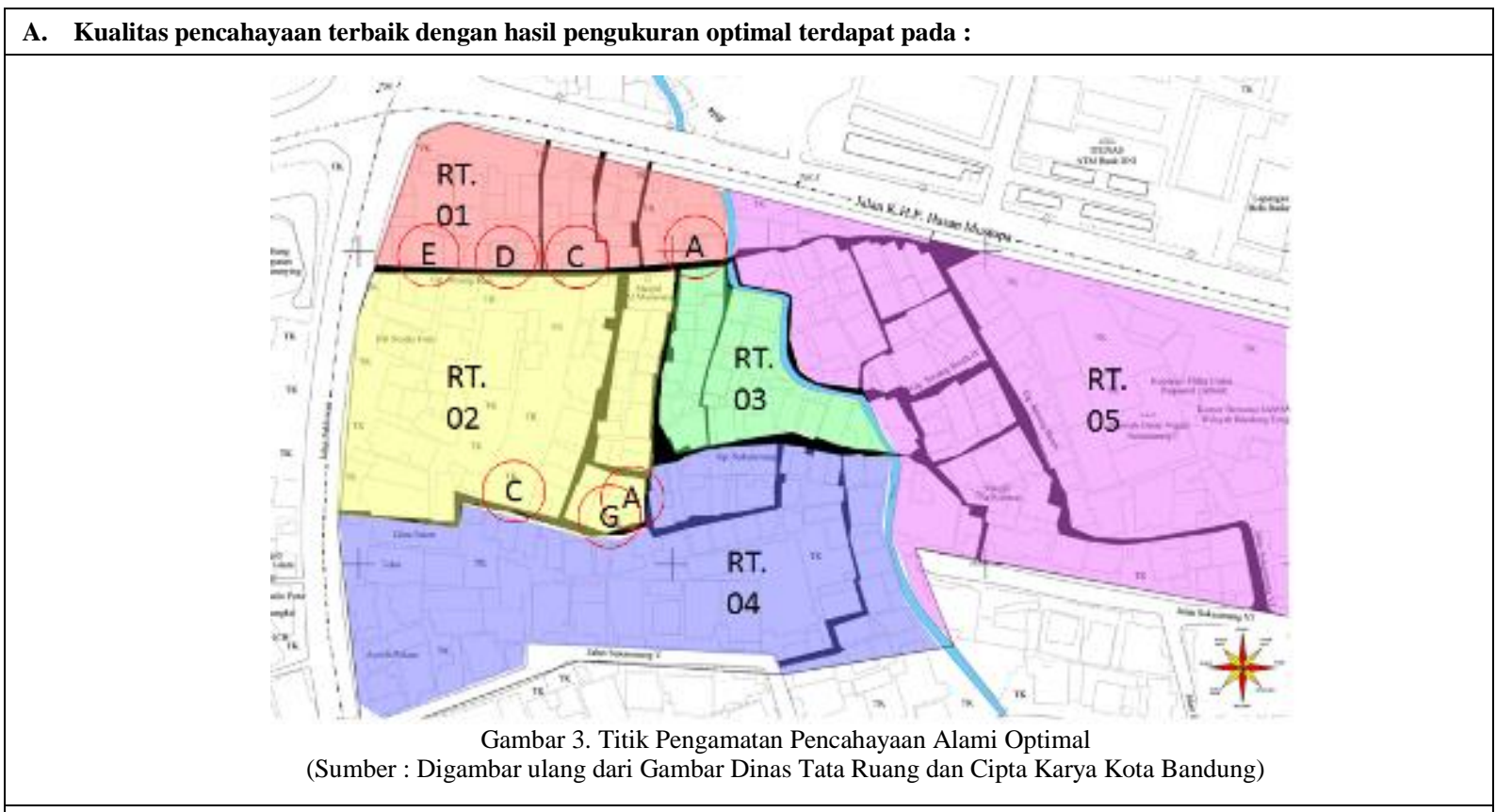

- $\quad$ Tipologi A pada RT 01, Area A arah Timur-Barat dengan rasio tinggi bangunan dan lebar jalan 1:1:2

- $\quad$ Tipologi C pada RT 01, Area A arah Timur-Barat dengan rasio tinggi bangunan dan lebar jalan 1:1:2

- $\quad$ Tipologi D pada RT 01, Area A arah Timur-Barat dengan rasio tinggi bangunan dan lebar jalan 3:2:3

- Tipologi E pada RT 01, Area A arah Timur-Barat dengan rasio tinggi bangunan dan lebar jalan 3:4:6

- Tipologi A pada RT 02, arah Utara-Selatan dengan rasio tinggi bangunan dan lebar jalan $3: 2: 3$

- $\quad$ Tipologi C pada RT 02, arah Barat Laut-Tenggara dengan rasio tinggi bangunan dan lebar jalan $3: 1: 8$

- $\quad$ Tipologi G pada RT 05, arah Barat Laut-Tenggara dengan rasio tinggi bangunan dan lebar jalan $1: 2: 3$

B. Kualitas pencahayaan yang Tidak memenuhi standar pencahayaan, diantaranya :

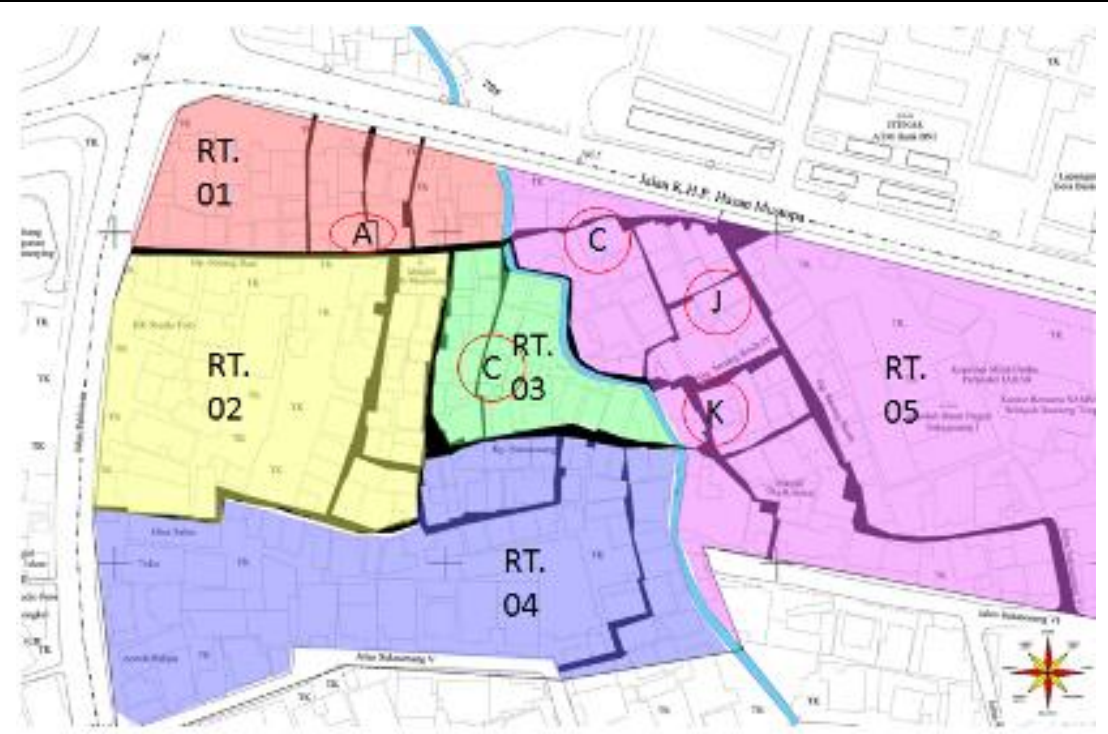

Gambar 4. Titik Pengamatan Pencahayaan Alami Tidak Optimal

(Sumber : Digambar ulang dari Gambar Dinas Tata Ruang dan Cipta Karya Kota Bandung)

- $\quad$ Tipologi A pada RT 01, Area C arah Utara-Selatan, dengan rasio tinggi bangunan dan lebar jalan6:1:7

- $\quad$ Tipologi C pada RT 03, arah Timur Laut-Barat Daya, dengan rasio tinggi bangunan dan lebar jalan 6:1:7

- $\quad$ Tipologi C pada RT 05, arah Timur-Barat, dengan rasio tinggi bangunan dan lebar jalan 3:1:6

- $\quad$ Tipologi J pada RT 05, arah Barat Laut-Tenggara, dengan rasio tinggi bangunan dan lebar jalan 7:2:7

- $\quad$ Tipologi K pada RT 05, arah Timur Laut-Barat Daya, dengan rasio tinggi bangunan dan lebar jalan 7:2:7

C.Tipologi lainnya dinyatakan telah memenuhi standar walaupun tidak mencapai pencahayaan yang optimal. 


\section{KESIMPULAN}

Area pengamatan terdiri dari 5 RT yaitu pada Kampung Sukasenang RW15, RT01-05. Berbatasan dengan Jalan PH.H. Mustofa pada arah Utara, Jalan Pahlawan pada arah Barat, Jalan Sukasenang VI di arah Selatan, dan Jalan Sukasenang di arah Timur. Dimensi gang pada kampung tersebut memiliki lebar antara $70 \mathrm{~cm}-5,2 \mathrm{~m}$. Aktivitas-aktivitas keseharian masyarakat yang dilakukan di ruang gang tidak terbatas pada aktivitas publik saja tetapi juga aktivitas pribadi. Berdasarkan pengamatan yang sudah dilakukan dan analisa antara kondisi lapangan pada tinjauan khusus dengan standarisasi pencahayaan maka kesimpulan dapat dilihat pada Tabel 7.

Tabel 7. Kesimpulan

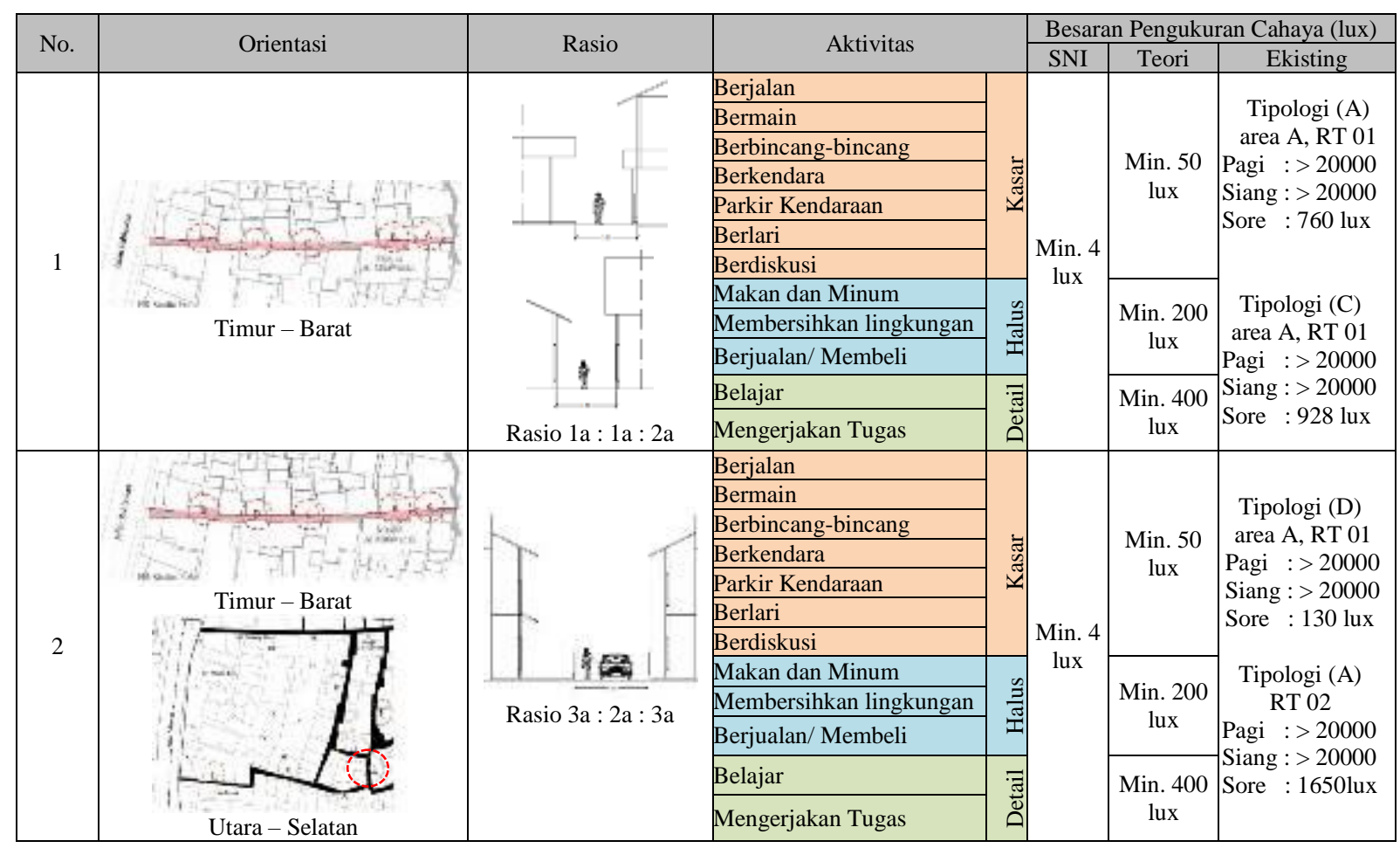

- Rasio terbaik antara tinggi bangunan dengan lebar jalan untuk mendapatkan kualitas pencahayaan yang optimal adalah 1:1:2 dan 3:2:3.

- Arah gang terbaik untuk mendapatkan kualitas pencahayaan yang optimal yaitu gang dengan arah Timur-Barat dan Utara-Selatan.

- Kualitas pencahayaan telah ideal pada gang di kawasan Sukasenang untuk beberapa kegiatan dalam klasifikasi kasar, diantaranya : berjalan, bermain, berbincang-bincang, parkir kendaraan, berlari, dan berdiskusi. Untuk kegiatan halus dan detail, tidak semua gang ideal dalam kualitas pencahayaannya.

\section{DAFTAR PUSTAKA}

[1] Kamus Besar Bahasa Indonesia

[2] Zahnd, Marcus, 1999, Perancangan Kota Secara Terpadu, Kanisius, Yogyakarta.

[3] SNI Tata Cara Perancangan Sistem Pencahayaan Buatan pada Bangunan Gedung, 2000

[4] Shirvani, Hamid, 1985, The Urban Design Process, Van Nostrand Reinhold Company, New York, USA.

[5] Latifah, Nur Laela, 2015, Fisika Bangunan 2, Griya Kreasi, Jakarta. 